\author{
PaweŁ Borecki
}

\title{
Państwo laickie w świetle dorobku współczesnego konstytucjonalizmu europejskiego
}

\section{Wprowadzenie. Specyfika religijno-światopoglądowa Europy}

Pojęcie państwa laickiego (świeckiego) posiada ugruntowaną interpretację w doktrynie prawa wyznaniowego ${ }^{1}$. Jako najistotniejsze cechy tego typu państwa wskazuje się jego rozdzielenie organizacyjne wobec związków wyznaniowych, odrębność funkcjonalną wymienionych podmiotów, niekompetencję państwa w sprawach religii, w tym w sprawach wewnętrznych wspólnot konfesyjnych, a zarazem niekompetencję związków wyznaniowych w dziedzinie sprawowania władzy publicznej. Konsekwencją tego jest względna niezależność związków wyznaniowych wobec państwa, przejawiająca się w ich autonomii prawnej oraz wewnętrznej samorządności. Zwraca się uwagę na niewyznaniowy charakter państwa, brak wyznania oficjalnego (państwowego). Państwo świeckie jest co do zasady niezainteresowane kwestią religii czy światopoglądów wyznawanych przez obywateli. Korelatem tego jest zapewnienie jednostce tzw. prawa do milczenia we wspomnianych sprawach. Podkreśla się, że państwo laickie winno być neutralne światopoglądowo. W państwie świeckim człowiek indywidualnie oraz w mniejszym lub większym kolektywie ma zapewnioną w wymiarze prawnym wolność sumienia i wyznania. W szczególności nauczanie religii w szkolnictwie publicznym (państwowym) ma charakter fakultatywny albo w ogóle nie występuje.

Pojęcie „kontynent europejski” jest terminem umownym, o charakterze geograficzno-kulturowym. Stary Kontynent stanowi zachodnią część Eurazji, którą zajmują w całości

1 M. Pietrzak, Demokratyczne, świeckie pañstwo prawne, Warszawa 1999, s.123-153; idem, Prawo wyznaniowe, Warszawa 2010, s. 92-101; P. Borecki, Laickośc państwa w świetle dorobku powojennego konstytucjonalizmu, [w:] Cuius regio, eius religio? Publikacja po Zjeździe Historyków Państwa i Prawa, t. I, Lublin 2006, t. II, Lublin 2008, s. 484-504; R.M. Małajny, Państwo świeckie (rozdziat kościota od państwa), [w:] Leksykon prawa wyznaniowego. 100 podstawowych pojęć, red. A. Mazglewski, Warszawa 2014, s. 271-290. Cf. G. Haarscher, Laickość, Warszawa 2004, s. 21. 
bądź częściowo terytoria 47 państw². Są one skupione, z wyjątkiem Białorusi, w Radzie Europy, do której należą także państwa południowego Kaukazu, znajdujące się poza granicami geograficznymi Europy: Gruzja, Armenia i Azerbejdżan³. Czynnikiem w istotnej mierze określającym zakres Europy jest szeroko rozumiana kultura, której jednym z fundamentów jest chrześcijaństwo.

Europa jest kontynentem szczególnym pod względem religii i innych odmian światopoglądów. Dotyczy to zarówno dziejów rzeczonych zjawisk w wymiarze społecznym, jak i ich odniesień do państwa. Na Starym Kontynencie tradycja kościoła (wyznania) państwowego jest wciąż żywotna ${ }^{4}$. Należy przy tym zwrócić uwagę na zróżnicowanie doświadczeń historycznych mieszkańców Europy. Wśród mieszkańców zachodniej części Starego Kontynentu, a także Niemiec i Czech zakorzeniona jest pamięć o wojnach na tle religijnych, szczególnie w wiekach XVI i XVII. Religia jawi się im zatem jako pierwiastek konfliktogenny, katalizujący podziały społeczne, zagrażający jedności państwowości. Natomiast w Europie Środkowej, Wschodniej, częściowo Południowej, a także w Irlandii religia i będące jej nośnikiem właściwe Kościoły chrześcijańskie - katolicki, prawosławne i protestanckie - okazały się czynnikami służącymi wykształceniu i zachowaniu tożsamości narodowej. Kler był niejednokrotnie warstwą przywódczą w walce o narodową emancypację.

Znamienny dla Europy jest relatywnie wysoki, wyższy niż na innych kontynentach, odsetek ateistów, agnostyków i osób nieidentyfikujących się z żadnym z oficjalnie działających związków wyznaniowych. Na początku XXI wieku 73,5\% ludności Europy stanowili chrześcijanie, 1,6\% - muzułmanie, 0,3\% - żydzi, 0,1\% - hindusi, 0,04\% - buddyści, $0,07 \%$ - wyznawcy innych religii, lecz aż $24,4 \%$ populacji to ateiści i bezwyznaniowcy 5 . Uzmysławia to, że szczególnie Europa doświadczyła procesów laicyzacji oraz prywatyzacji przekonań w sprawach religijnych. Należy zaznaczyć, że w dziedzinie religijności utrzymują się znaczne różnice między poszczególnymi państwami europejskimi ${ }^{6}$. Fala

2 W granicach Europy znajdują się w całości 44 państwa. Republika Kosowo nie cieszy się powszechnym uznaniem międzynarodowym. Ponadto należy odnotować, że państwem faktycznie niepodległym, lecz niemającym uznania międzynarodowego jest Naddniestrze. Stary Kontynent obejmuje także 25\% terytorium Rosji, niewielką część Turcji - 23 tys. km kw. oraz część terytorium Kazachstanu - 123 tys. km kw. Cf. Religia. Encyklopedia PWN, red. T. Gadacz, B. Milerski, t. 3, Warszawa 2001, s. 468.

3 W Azerbejdżanie w 2015 r. odbyły się I Europejskie Igrzyska Olimpijskie.

4 Cf. L. Garlicki, Wolnośs sumienia i wyznania - status wspólnot religijnych, „Biuletyn Trybunału Konstytucyjnego", 1999, nr specjalny, s. 34 i 39-40.

5 Religia. Encyklopedia PWN, op. cit., s. 469.

6 Według badań Instytutu Gallupa z 2014 r. określiły się odpowiednio, że są osobami religijnymi, niereligijnymi, ateistami, albo nie udzieliły odpowiedzi następujące odsetki badanych w wybranych państwach europejskich: Polska - 86\%,10\%, 2\%, 2\%; Turcja - 79\%, 13\%, 2\%, 6\%; Rumunia - 77\%, 16\%, 1\%, 6\%; Włochy - 74\%, 18\%, 6\%, 3\%; Grecja - 71\%, 15\%, 6\%, 8\%; Rosja - 70\%, 18\%, 5\%, 8\%; Portugalia-60\%, 28\%, 9\%, 2\%; Bułgaria-52\%, 36\%, 3\%, 8\%; Irlandia-45\%, 41\%, 10\%, 
masowej migracji wyznawców islamu z rejonu Bliskiego i Środkowego Wschodu oraz Afryki czyni sytuację religijną w wymiarze demograficznym dynamiczną ${ }^{7}$. Ujawniają się nowe napięcia i konflikty na tle religijnym i obyczajowym w społeczeństwach dotychczas stabilnych. Wzrostowi ich konfesyjnej i etnicznej heterogeniczności towarzyszy m.in. wzrost ksenofobii oraz poczucia zagrożenia przez terroryzm islamski. Opisane zjawiska znajdują odzwierciedlenie m.in. w zmianach prawa wyznaniowego i polityki wyznaniowej w niektórych państwach.

Charakter państwa ze względu na religię i światopogląd w pierwszej kolejności powinna określać jego konstytucja (ustawa zasadnicza). Zgodnie z powszechnie przyjętą w Europie kontynentalnej zasadą konstytucjonalizmu ustawa zasadnicza ma najwyższą moc prawną w państwie. Powinna zatem determinować inne akty normatywne w analizowanym zakresie, zarówno co do ich treści, jak i formy prawnej oraz trybu ustanowienia. Należy zaznaczyć, że niejednokrotnie postanowienia konstytucji dotyczące: charakteru państwa ze względu na religię lub światopogląd oraz systemu relacji między państwem a związkami wyznaniowymi mają charakter lapidarny, wręcz ogólnikowy. Mają formę kilku krótkich przepisów zawierających klauzule generalne. Nie należą do wyjątków przypadki unormowania tych kwestii w pojedynczych jednostkach redakcyjnych konstytucji ${ }^{8}$. Taki stan normatywny wskazuje, że kwestie wyznaniowe nie należą do istotnych w życiu publicznym w danym państwie. W konsekwencji określenie charakteru państwa pod względem religijno-światopoglądowym jedynie na podstawie treści aktów ustrojodawczych nie daje jednoznacznych rezultatów, a niekiedy okazuje się niemożliwe, gdy konstytucja w tej dziedzinie milczy ${ }^{9}$. Główny ciężar regulacji wspomnianych zagadnień spoczywa na ustawodawcy oraz na orzecznictwie sądowym, przede wszystkim orzecznictwie sądów (trybunałów) konstytucyjnych. Należy zauważyć, że regulacje ustawowe odbiegają, i to istotnie, od znaczenia konstytucyjnych klauzul wyznaniowych ${ }^{10}$. Wreszcie

5\%; Belgia - 44\%, 30\%, 18\%, 7\%; Dania - 42\%, 40\%, 12\%, 7\%; Francja - 40\%, 35\%, 18\%, 7\%; Łotwa - 40\%, 41\%, 9\%, 10\%; Austria - 39\%, 44\%, 10\%, 6\%; Szwajcaria - 38\%, 46\%, 12\%, 4\%; Hiszpania - 37\%, 35\%, 20\%, 8\%; Niemcy - 34\%, 42\%, 17\%, 7\%; Zjednoczone Królestwo - 30\%, 53\%, 13\%, 4\%; Niderlandy - 26\%, 51\%, 15\%, 8\%; Czechy - 23\%, 45\%, 30\%, 2\%; Szwecja - 19\%, 59\%, 17\%, 6\%. V. http://www.eurel.info/spip.php?article2588\&lang=fr [dostęp: 18.12.2015].

7 Według Biura Wysokiego Komisarza ONZ ds. Uchodźców tylko w 2015 r. do Europy przybyło ponad 1 mln migrantów. Mężczyźni stanowią 58\% migrantów, kobiety - 17\%, a dzieci - 25\%. Syryjczycy to $49 \%$ rzeczonej grupy, Afgańczycy - 21\%, Irakijczycy - 8\%. Pozostali migranci wywodzą się z: Erytrei, Pakistanu, Nigerii, Somalii, Sudanu, Gambii i Mali.

8 Art. 8 konstytucji Republiki Kosowa z 2008 r. i art. 9 konstytucji Księstwa Monako z 1962 r.

9 Przykładem współczesnej europejskiej ustawy zasadniczej przemilczającej zagadnienie stosunku państwa do religii, światopoglądów oraz związków wyznaniowych jest konstytucja Holandii z 1815 r. w jej aktualnym brzmieniu, konstytucja Finlandii z 1999 r. oraz konstytucja Szwajcarii z 1999 r.

$10 \mathrm{Na}$ przykład pomimo tego, że konstytucja Rosji z 1993 r. w art. 14 określa to państwo jako świeckie, oddzielone od związków wyznaniowych, to ustawodawca federalny wyraźnie dowartościowuje prawosławie. W arendzie ustawy z września 1997 r. o wolności sumienia i związ- 
realia polityki wyznaniowej państwa mogą być w ograniczonym zakresie determinowane zarówno przez postanowienia ustawy zasadniczej, jak i treść aktów ustawodawczych dotyczących kwestii konfesyjnych. Wymownym przykładem w tym zakresie jest Rzeczpospolita Polska, która zgodnie z art. 10 ust. 1 ustawy z dnia 17 maja 1989 r. o gwarancjach wolności sumienia i wyznania ${ }^{11}$,jest państwem świeckim, neutralnym w sprawach religii i przekonań”, to w praktyce życia publicznego, w mniejszym stopniu w ustawodawstwie, ujawnia wiele cech państwa wyznaniowego o charakterze chrześcijańskim (katolickim) ${ }^{12}$.

\section{Świeckość państwa, jego awyznaniowy charakter}

Klauzula świeckości (laickości) państwa nie jest często wprost artykułowana w konstytucjach państw europejskich. Ma to miejsce w ustawach zasadniczych 14\% państw terytorialnie należących (w całości bądź w części) do Starego Kontynentu lub będących członkami Rady Europy. Są to konstytucje: francuska z 1958 r. (art. 1) $)^{13}$, turecka z 1982 r. $(\text { art. 2) })^{14}$, rosyjska z 1993 r. (art. 14 ust. 1) ${ }^{15}$, kazachska z 1995 r. $\left(\right.$ art. 1) ${ }^{16}$, azerbejdżańska z 1995 r. (art. 18), serbska (art. 11) ${ }^{17}$ oraz kosowska z 2008 r. (art. 8) ${ }^{18}$. Znamienne, że wspomnianej zasadzie, jako określającej charakter, a wręcz istotę danej państwowości, ustrojodawca nadał wysoką rangę. Jest wyrażana w czołowych jednostkach systematyzacyjnych konstytucji, dotyczących głównych (podstawowych) zasad ustroju. Można tę klauzulę uznać za trwały element europejskiego konstytucjonalizmu. W ciągu ponad

kach wyznaniowych czytamy m.in. „[...] uznając szczególną rolę prawosławia w historii Rosji, w kształtowaniu i rozwijaniu jej życia duchowego, szanując chrześcijaństwo, islam, buddyzm, judaizm i inne religie stanowiące nieodłączną część spuścizny historycznej narodów Rosji [...]”.

11 T.j. Dz.U. 2005 nr 231 poz. 1965 z późn. zm.

12 P. Borecki, Elementy konfesjonalizacji państwa we wspótczesnej Polsce, [w:] Państwo wyznaniowe. Doktryna, prawo i praktyka, red. J. Szymanek, Warszawa 2011, s. 148-164.

13 Konstytucje pañstw Unii Europejskiej, red. W. Staśkiewicz, Warszawa 2011, s. 273. Zasada, że Francja jest państwem laickim, została wyrażona po raz pierwszy w konstytucji IV Republiki z 1946 r. Zapewne pod wpływem wzorców francuskich zasadę świeckości państwa wprost wyartykułowano w konstytucjach innych państw powstałych po II wojnie światowej w wyniku rozpadu francuskiego imperium kolonialnego: Mali z 1960 r., Nigru z 1960 r., Republiki Wybrzeża Kości Słoniowej z 1960 r., Kamerunu z 1961 r., Konga-Brazzaville z 1963 r., Senegalu z 1963 r., Dahomeju z 1964 r. czy Republiki Środkowoafrykańskiej z 1964 r.

14 https://www.constituteproject.org/constitution/Turkey_2002.pdf [dostęp:14.12.2015]. WTurcji zasadę państwa świeckiego pierwszy raz konstytucjonalizowano w $1961 \mathrm{r}$. Pomimo zniesienia kalifatu konstytucja z 1924 r. stanowiła jeszcze, że religią państwa tureckiego jest islam (art. 2). Cf. http://genckaya.bilkent.edu.tr/1924constitution.pdf [dostęp: 14.12.2015].

15 http://libr.sejm.gov.pl/tek01/txt/konst/rosja.html [dostęp: 14.12.2015].

$16 \mathrm{ftp} / / / \mathrm{ftp}$.fao.org/upload/eims_object/Photo_library/KazakhstanConstitution.pdf [dostęp: 14.12. 2015].

17 http://wipo.int/wipolex/en/text.jsp?file_id=191258 [dostęp: 23.12.2015].

$18 \mathrm{http} / /$ www.assembly-kosova.org/common/docs/Constitution1\%20of\%20the\%20Republic\%20 of\%20Kosovo.pdf [dostęp: 15. 12.2015]. 
60 lat została ona upowszechniona w państwach europejskich o różnym położeniu geograficznym, o zróżnicowanej tradycji ustrojowej i konfesyjnej.

Znamienne, że we Francji w XX wieku pojęcie laickości ewoluowało. W 1905 r.laickość państwa, rozumiana jako „laickość agresywna” (laïcisme agressif), była doktryną polityczną zmierzającą do eliminacji zobszaru spraw publicznych wpływów religijnych,w szczególności Kościoła katolickiego. Obecnie laickość państwa, rozumiana jako „laickość pozytywna” (laïcité positive), służy jako podstawa zasad prawnych mających na celu zapewnienie neutralności władz państwowych w sprawach religii oraz zabezpieczenia równego traktowania różnych przejawów życia religijnego ${ }^{19}$. Laickie państwo republikańskie jest przestrzenią chroniąca prawa człowieka i obywatela - to podstawowa teza doktryny państwa i prawa współczesnej Francji ${ }^{20}$. Nie jest ono utożsamiane z państwem ateistycznym. Jak stwierdził w 1976 r. sekretarz generalny Francuskiej Partii Komunistycznej Georges Marchais:

Chcemy, aby we Francji socjalistycznej respektowane były prawa i swobody wszystkich obywateli, wierzących i niewierzących. Chcemy państwa, które nie będzie własnością żadnej partii, żadnej grupy ludzi, państwa ani ateistycznego, ani chrześcijańskiego, ale po prostu świeckiego. To znaczy państwa, które zapewni materialne i polityczne warunki swobodnego rozwoju i swobody wypowiadania się wszystkim kierunkom myślowym. W tym zawiera się prawo do wolności sumienia i religii²1.

Według sentencjonalnej opinii większości Sądu Najwyższego Stanów Zjednoczonych Ameryki (SN USA) w sprawie Allegheny County v. Greater Pittsburgh ACLU z 1989 r.:

Państwo świeckie nie jest tym samym, co państwo ateistyczne czy antyreligijne. Państwo świeckie nie czyni swoją ideologią ani ateizmu, ani religii. W państwie świeckim nie występuje ortodoksja w sprawach religijnych ${ }^{22}$.

Reasumując, częstokroć ustalenie, czy dana ustawa zasadnicza wyraża ideę państwa świeckiego, wymaga uwzględnienia także innych klauzul konstytucyjnych. Są to przede wszystkim te określające charakter państwa ze względu na religię, światopogląd czy ideologie lub dotyczące jego relacji ze związkami wyznaniowymi bądź - co zdecydowanie rzadsze - z organizacjami światopoglądowymi.

19 Orzecznictwo konstytucyjne w sprawach wolności religijnej oraz system wyznań i swobody wyznaniowej we Francji. Referat Francuskiej Rady Konstytucyjnej, dane zebrał B. Gaudemet-Basdevant [mps powiel.], Archiwum Trybunału Konstytucyjnego (ATK), s. 9.

20 H. Łakomy, Państwo a Kościót we Francji. Historia i wspótczesność, Kraków 1999, s. 62.

21 „L'Humanitê" z 11 czerwca 1976 r., cit. per: M. Pietrzak, Prawo wyznaniowe, Warszawa 1988, s. 89.

22 S. Frankowski, R. Goldman, E. Łętowska, Sąd Najwyższy USA. Prawa i wolności obywatelskie, Warszawa 1996, s. 168. 
Świeckość (laickość) państwa jest przede wszystkim konsekwencją odrzucenia religii państwowej (oficjalnej). Analizowany model państwa stanowi antytezę państwa wyznaniowego, czyli takiego, w którym istnieje konfesja czy też Kościół oficjalny. Za państwa świeckie w minimalnym znaczeniu można uznać te, które w swych ustawach zasadniczych deklarują nieistnienie wyznania (religii) czy związku wyznaniowego (Kościoła) o charakterze państwowym (oficjalnym). Nieistnienie Kościoła państwowego deklarują konstytucje: Niemiec z 1949 r. (art. 137 utrzymanych w mocy postanowień konstytucji niemieckiej z 1919 r.) i Estonii z 1992 r. (§ 40). Stwierdzenia, że żadna religia nie może być uznana za państwową lub obowiązującą czy też nieistnienie religii państwowej (wyznania państwowego) zawarto odpowiednio w konstytucjach: Hiszpanii z 1978 r. (art. 16 ust. 3), Litwy z 1992 r. (art. 43), Rosji z 1993 r. (art. 14), Ukrainy z 1996 r. (art. 35), Albanii z 1998 r. (art. 10 ust. 1) ${ }^{23}$ i Serbii z 2006 r. (art. 11).

Awyznaniowości państwa niektóre ustawy zasadnicze nadają szerszy zakres, odrzucając, zapewne pod wpływem doświadczeń państwowości komunistycznej, także wszelką ideologię państwową ${ }^{24}$. Świeckość państwa w świetle dorobku niektórych państw postkomunistycznych, zwłaszcza europejskich, oznacza jego aideologiczność ${ }^{25}$. Współczesne państwo demokratyczne, jak czytamy w konstytucjach rosyjskiej i kazachskiej uznaje ideologiczną różnorodność. Żadna ideologia nie może być zatem uznana za oficjalną (państwową) ${ }^{26}$. Według czeskiej Karty Podstawowych Praw i Wolności z 1992 r. państwo jest oparte na wartościach demokratycznych i nie może być skrępowane ani wyłączną ideologią, ani wyznaniem religijnym. Oddzielone od państwa zostają nie tylko związki wyznaniowe, ale także - jak stanowi konstytucja Słowacji z 1992 r. - partie i ruchy polityczne oraz związki, towarzystwa i inne zrzeszenia.

\section{Zasada rozdziału państwa i związków wyznaniowych}

Świecki charakter państwa jest generalnie oceniany jako konsekwencja przyjęcia zasady rozdziału państwa i związków wyznaniowych. Niektórzy przedstawiciele doktryny pra-

23 http://www.osce.org/albania/41888?download=true [dostęp: 17.12.2015].

24 Konstytucja Ludowej Socjalistycznej Republiki Albanii z 1976 r. wprost stanowiła, że ideologią panującą jest marksizm-leninizm. Podobnie ustrojodawca chiński w 1978 r. jako kierowniczą ideologię państwa uznał marksizm-leninizm oraz idee Mao Tse-tunga, zaś konstytucja wietnamska z 1980 r. czyniła marksizm-leninizm ideologią wytyczającą kierunek rozwoju społeczeństwa. Państwa komunistyczne były zatem strukturami sui generis wyznaniowymi. Władze dążyły bowiem do narzucenia całemu społeczeństwu ideologii ateistycznej, która miała zastąpić religię. Towarzyszyły temu próby wprowadzenia surogatów świąt religijnych, ceremoniałów inicjacyjnych czy wręcz kultu przywódców partyjno-państwowych.

25 Szerzej: B. Górowska, Stosunki państwo - Kościót w konstytucjach państw postkomunistycznych, „Więź" 1993, nr 6, s. 66-79.

26 Cf. m.in. art. 13 konstytucji Rosji z 1993 r., art. 5 konstytucji Mołdowy z 1994 r., art. 15 konstytucji Ukrainy z 1996 r. 
wa wyznaniowego utożsamiają wręcz te zasady ustrojowe. Owa prawidłowość ma jednak wyjątki. W kręgu europejskiego konstytucjonalizmu istnieją państwa, które deklarując w swych ustawach zasadniczych rozdział wobec związków wyznaniowych wskazują zarazem na szczególną pozycję określonego Kkościoła lub wyznania (religii). Można przyjąć, iż w istocie państwa te mają cechy państw konfesyjnych.

W konstytucji bułgarskiej z 1991 r. uznano wyznanie prawosławne za religię tradycyjną w Republice Bułgarii ${ }^{27}$. Ustrojodawca armeński stwierdza, że Republika Armenii uznaje szczególną rolę Świętego Armeńskiego Kościoła Apostolskiego jako kościoła narodowego w życiu duchowym, dla rozwoju kultury narodowej i zachowaniu tożsamości narodowej narodu Armenii ${ }^{28}$. Konstytucja Gruzji stanowi w art. 9 ust. 1, że związki wyznaniowe są niezależne od państwa ${ }^{29}$. Dokonuje zarazem wyraźnej aprecjacji Apostolskiego Ortodoksyjnego Kościoła Gruzji, uznając jego historyczną rolą oraz przewidując regulacje jego odniesień z państwem w formie Porozumienia Konstytucyjnego. W przypadku ustrojodawcy węgierskiego można mówić o odejściu od neutralności światopoglądowej skoro mimo jurydyzacji zasady rozdzielenia państwa i związków wyznaniowych ${ }^{30}$, arenda konstytucji z 2011 r. rozpoczyna się od wezwania: Boże, błogosław Węgrów! ${ }^{13}$. Współczesna ustawa zasadnicza Węgier ma wyraźnie charakter filochrześcijański. W jej preambule wyraża się dumę, iż „król, Święty Stefan [...] uczynił naszą ojczyznę częścią chrześcijańskiej Europy, uznaje się, że chrześcijaństwo miało szczególną rolę w przetrwaniu narodu”. Korelatem dowartościowania jednego wyznania czy związku konfesyjnego jest przemilczenie w wymienionych konstytucjach zasady równości czy równouprawnienia związków wyznaniowych.

We współczesnej Europie zakres konstytucjonalizacji formuły rozdziału, oddzielenia, czy separacji państwa od/i związków wyznaniowych pozwala odrzucić pogląd formułowany przez jej krytyków, że jest to zasada charakterystyczna dla konstytucjonalizmu komunistycznego, mająca komunistyczny rodowód $\mathrm{d}^{32}$. Historycznie prekursorem jurydyzacji formuły oddzielenia (rozdziału) państwa od/i Kościoła była rewolucyjna Francja, której parlament - Konwent - 21 lutego 1795 r. przyjął dekret o rozdziale państwa i Kościoła ${ }^{33}$.

27 http://libr.sejm.gov.pl/tek01/txt/konst/portugalia.html [dostęp: 14.12.2015].

$28 \mathrm{http} / /$ www.ilo.org/dyn/travail/docs/960/Constitution\%20of\%20the\%20Republic\%20of\%20 Armenia.pdf [dostęp: 14.12.2015].

29 http://www.parliament.ge/files/68_1944_951190_CONSTIT_27_12.06.pdf [dostęp: 14.12.2015]. 30 Zasadę, że kościół jest oddzielony od państwa, wprowadziła konstytucja Węgierskiej Republiki Ludowej z 18 sierpnia 1949 r. Nastąpiło to zapewne pod wpływem stalinowskiej konstytucji ZSRR z 1936 r. Trzeba jednak zaznaczyć, że wspomniana zasada została utrzymana w wielokrotnie nowelizowanej po przełomie ustrojowym lat 1989-1990 konstytucji Republiki Węgierskiej. Cf. http://libr.sejm.gov.p1/tek01/txt/konst/wegry.html [dostęp: 14.12.2015].

31 http://libr.sejm.gov.pl/tek01/txt/konst/wegry2011.html [dostęp: 14.12.2015].

32 „Komisja Konstytucyjna Zgromadzenia Narodowego. Biuletyn” 1995, t. XIV, s. 70.

33 Jurydyzacji odpowiedniej formuły (i zasady ustrojowej) dokonano ponownie we Francji dekretem Komuny Paryskiej z dnia 2 kwietnia 1871 r. o rozdziale Kościoła od państwa oraz ustawą 
Współcześnie powyższe sfomułowania zawierają odpowiednio konstytucje: Portugalii z 1976 r. (art. 41 ust. 4) ${ }^{34}$, Chorwacji z 1990 r. (art. 41) 35, Bułgarii z 1991 (art. 13 ust. 2), Macedonii z 1991 r. (art. 19) ${ }^{36}$, Słowenii z 1991 r. (art. 7), Rosji z 1993 r. (art. 14 ust. 2), Mołdawii z 1994 r. (art. 31 ust. 6) 37, Azerbejdżanu z 1995 r. (art. 18) 38, Armenii z 1995 r. (art. 8 ust. 1), Ukrainy (art. 35), Serbii z 2006 r. (art. 44) $)^{39}$, Czarnogóry z 2007 r. (art. 14) ${ }^{40}$ czy Węgier z 2011 r. (art. VII ust. 2). Spotykamy je więc w ustawach zasadniczych 25\% analizowanych państw.

Ponieważ zasada rozdziału państwa i związków wyznaniowych w państwach demokratycznych ma utrwaloną i szczegółową wykładnię, to już samo jej bezpośrednie sformułowanie w konstytucji można uznać za wystarczające dla określenia relacji między rzeczonymi podmiotami. Ustrojodawca w wielu państwach Europy od początku lat 90. XX wieku, zapewne pod wpływem negatywnych doświadczeń okresu rządów komunistycznych, doprecyzowuje zasadę rozdziału państwa i związków wyznaniowych lub wprowadza klauzule wyznaniowe o charakterze zastępczym. Można przypuszczać, że ma to zapewnić nieantagonistyczne relacje między państwem i Kościołem, względnie ochronę związków wyznaniowych przed różnymi formami presji ze strony państwa.

\section{Niezależność organizacyjna i funkcjonalna państwa i Kościoła. Autonomia związków wyznaniowych}

Rozdział państwa i związków wyznaniowych oznacza przede wszystkim oddzielenie organizacyjne tych podmiotów. W szczególności powinien temu towarzyszyć zakaz łączenia stanowisk kierowniczych w aparacie państwowym oraz w związkach wyznaniowych. Nie spotykamy się jednak expressis verbis z tego rodzaju zakazem w konstytucjach państw europejskich, które mogłyby być zaklasyfikowane jako państwa świeckie (laickie). Współcześnie w Europie nie występuje też konstytucyjne ograniczenie praw wyborczych duchowieństwa. Tego typu ograniczenia występowały w aktach ustrojodawczych niektórych państw komunistycznych w pierwszych latach umacniania się nowego

z dnia 9 grudnia 1905 r. o rozdziale Kościołów od państwa. Dopiero dekret Rady Komisarzy Ludowych z 28 stycznia 1918 r. o oddzieleniu Kościoła od państwa i szkoły od Kościoła ustanowił specyficzną formę rozdziału w Rosji bolszewickiej. Cf. H. Światkowski, Stosunek państwa do kościoła w różnych krajach, Warszawa 1952, s. 78-84, 107-108.

34 http://libr.sejm.gov.pl/tek01/txt/konst/portugalia.html [dostęp: 14.12.2015].

35 Konstytucja Republiki Chorwacji, tłum. T.M. Wójcik, wstęp A. i L. Garliccy, Warszawa 1995, s. 26.

36 http://libr.sejm.gov.pl/tek01/txt/konst/macedonia.html [dostęp: 14.12.2015].

37 http://swp4.wspolnotapolska.org.pl/prawa_mniejszosci/art/Konstytucja-Republiki-Moldowy,41.html [dostęp: 15.12.2015].

38 http://icla.up.ac.za/.../Azerbeijan/Constitutution [dostęp: 15.12.2015].

39 http://www.wipo.int/wipolex/en/text.jsp?file_id=191258 [dostęp: 14.12.2015].

40 http://www.wipo.int/wipolex/en/text.jsp?file_id=187544\#LinkTarget_1462[dostęp:14.12.2015]. 
reżimu ${ }^{41}$. Obecnie jako wyjątek potwierdzający ową regułę należy traktować postanowienia konstytucji Azerbejdżanu, która pozbawia m.in. duchowieństwo biernego prawa wyborczego do parlamentu (art. 86 ust. III). W konsekwencji zgodnie z art. 100 rzeczonego aktu duchowni stanowią jedną $\mathrm{z}$ grup pozbawionych prawa kandydowania na urząd prezydenta Azerbejdżanu. Ograniczenia w sprawowaniu stanowisk we władzach publicznych mogą natomiast wynikać z prawa wewnętrznego związków wyznaniowych. Kodeks prawa kanonicznego z 1983 r. w kan. 285 § 3 zabrania duchowieństwu Kościoła katolickiego przyjmowania urzędów, z którymi łączy się wykonywanie władzy świeckiej ${ }^{42}$. Tak jednoznaczną regulację należy jednak uznać za wyjątek niż regułę wśród związków wyznaniowych działających na Starym Kontynencie.

Zasada świeckości państwa oznacza wykluczenie bezpośredniego wpływu religii, w tym związków wyznaniowych, na proces sprawowania władzy państwowej (publicznej). Bodaj najbardziej jednoznaczny zakaz tego rodzaju w Europie formułuje konstytucja Turcji z 1982 r. (art. 24), która zapewniając każdemu prawo do wolności sumienia, wyznania oraz przekonań, zabrania zarazem wykorzystywania i nadużywania religii lub rzeczy świętych w celu oparcia, choćby częściowo, podstawowego porządku społecznego, ekonomicznego, politycznego i prawnego państwa na dogmatach religijnych. W szerszym ujęciu zakaz taki przewidują konstytucje Federacji Rosyjskiej z 1993 r., Kazachstanu z 1995 r. oraz Ukrainy z 1996 r., ustanawiając kategoryczny zakaz uzurpacji władzy państwowej m.in. przez organizacje społeczne, w tym związki wyznaniowe. Swoistą formułę zakazu angażowania się związków wyznaniowych w działalność polityczną jest zakaz tworzenia partii o charakterze religijnym Współcześnie taki zakaz przewidują konstytucje Bułgarii z 1991 r. (art. 11 ust. 4) oraz Kazachstanu z 1993 r. (art. 5). Jest to prawdopodobnie próba zapobieżenia rozwojowi fundamentalizmu islamskiego. Natomiast ustrojodawca portugalski w 1976 r. ustanowił bardziej subtelne ograniczenia. Wyklucza bowiem używanie przez partie polityczne oraz związki zawodowe, przy zachowaniu ich autonomii programowej, m.in. nazw zawierających określenia związane z jakąkolwiek religią lub Kościołem oraz emblematów, które mogą być mylone z symbolami religijnymi. Według orzecznictwa portugalskiego Trybunału Konstytucyjnego zakaz konstytucyjny

41 Konstytucja Rosyjskiej Socjalistycznej Federacyjnej Republiki Rad z 1918 r. pozbawiała praw wyborczych zakonników i wtadze duchowne kościotów i kultów religijnych, kwalifikując ich à priori jako przeciwników nowego reżimu. Restrykcje te utrzymała konstytucja Rosyjskiej Socjalistycznej Federacyjnej Republiki Sowieckiej z 1925 r. Na jej wzór ograniczenia wprowadzały ustawy zasadnicze innych republik sowieckich. Podobnie konstytucja Mongolskiej Republiki Ludowej z 1924 r. pozbawiała praw wyborczych wyższe duchowieństwo lamaickie. Także twórcy konstytucji meksykańskiej z 1917 r. upatrywali w duchowieństwie przeciwników politycznych, skoro pozbawili księży biernego i czynnego prawa wyborczego, a także prawa tworzenia zrzeszeń dla celów.

42 Zgodnie z Kan. 287 § 2 duchowni nie mogą brać czynnego udziału w partiach politycznych ani w kierowaniu związkami zawodowymi, chyba że - zdaniem kompetentnej władzy kościelnej będzie wymagała tego obrona praw Kościoła lub rozwój dobra wspólnego. 
ma uniemożliwić wszelkie naruszenie dobrej wiary obywateli i zagwarantować warunki przejrzystości ich udziału w życiu politycznym, wyłączając możliwość lekceważenia religii lub Kościołów oraz chroniąc zasadę państwa niewyznaniowego i wolność sumienia ${ }^{43}$.

Niekiedy ustrojodawca wskazuje na szczególne aspekty odrębności organizacyjnej państwa i związków wyznaniowych. Konstytucja Belgii z 1831 r., ustanawiając swoisty system oddzielenia państwa od związków wyznaniowych, głosi:

\begin{abstract}
Państwo nie ma prawa interweniować ani w mianowanie, ani we wprowadzanie na urząd duchownych jakiegokolwiek wyznania, jak też zabraniać im utrzymywania kontaktów ze swymi przełożonymi lub publikowania swych aktów; w tym ostatnim przypadku stosuje się zwykłe zasady odpowiedzialności w dziedzinie prasy i publikacji ${ }^{44}$.
\end{abstract}

System belgijski dotyczący relacji państwo - związki wyznaniowe można określić jako rozdział selektywny ${ }^{45}$.

Odrębność organizacyjna związków wyznaniowych wobec państwa służy ich wewnętrznej samorządności i niezależności. $\mathrm{Na}$ ów komponent idei państwa świeckiego zwraca uwagę konstytucja Słowacji z 1992 r., stanowiąc: „Kościoły i wspólnoty religijne zarządzają samodzielnie swoimi sprawami, zwłaszcza ustanawiając swoje organy, swoich duchownych, zapewniając naukę religii i zakładając zakonne i inne kościelne instytucje niezależne od organów państwowych" (art. 24 ust. 3) ${ }^{46}$. Podobne sformułowania zawiera w art. 16 ust. 2 Karty Podstawowych Praw i Wolności Republiki Czeskiej z 1992 r. ${ }^{47}$

43 J. de Sousa E. Brito, Orzecznictwo konstytucyjne w dziedzinie wolności wyznaniowej w Portugalii [mps. powiel.], ATK, s. 15.

44 Zarazem jednak zgodnie $\mathrm{z}$ konstytucją ślub wyznaniowy winien być poprzedzony ślubem cywilnym, z wyjątkiem przypadków, które w razie potrzeby określi ustawa. V. http://libr.sejm.gov. $\mathrm{pl} /$ tek01/txt/konst/belgia.html [dostęp: 15.12.2015].

45 Podobne gwarancje, ale jedynie dla Kościoła katolickiego, zawiera konstytucja Luksemburga z 1868 r. Zgodnie z art. 22 tegoż aktu ingerencja państwa w powoływanie i obejmowanie stanowisk przez zwierzchników wspólnot kościelnych, tryb powoływania i odwoływania pozostałych duchownych, swoboda komunikowania się jednych i drugich ze swoimi przełożonymi i publikowania swoich aktów oraz stosunki Kościoła z państwem są przedmiotem umów podlegających przedłożeniu Izbie Deputowanych w zakresie przepisów, które wymagają jej interwencji. Cf. http://libr.sejm.gov.pl/tek01/txt/konst/luksemburg.html [dostęp: 15.12.2015]. W sumie można rzeczone gwarancje uznać pod względem proceduralnym za lepsze niż przewidziane przez ustrojodawcę belgijskiego, ponieważ ingerencja państwa w sferę organizacyjną Kościoła katolickiego uzależniona została w istocie od jego zgody wyrażonej w formie umowy. Luksemburg trudno jest wszakże w świetle jego ustawy zasadniczej zaliczyć do państw laickich (świeckich). Podczas referendum konstytucyjnego w czerwcu 2015 r. obywatele opowiedzieli się przeciwko zniesieniu finansowania przez państwo uznanych związków wyznaniowych.

46 http://libr.sejm.gov.pl/tek01/txt/konst/slowacja.html [dostęp: 15.12.2015].

$47 \mathrm{http}: / /$ swp4.wspolnotapolska.org.pl/prawa_mniejszosci/art/Karta-Podstawowych-Praw-i-Wolnosci,16.html [dostęp: 15.12.2015]. 
Konstytucja Litwy z 1992 r. podkreśla niezależność związków wyznaniowych od państwa w sferze ściśle konfesyjnej, stanowiąc: „Kościoły i organizacje religijne bez przeszkód głoszą swą naukę, odprawiają obrzędy, mają domy modlitwy, instytucje dobroczynne i szkoły przygotowujące duchownych" (art. 43 zd. 3) ${ }^{48}$. W tym przypadku można mówić o gwarancjach wolności kolektywnej praktykowania religii.

Niektóre ustawy zasadnicze państw klasyfikowanych jako państwa świeckie akcentują autonomię związków wyznaniowych, czyli ich prawo do samodzielnego tworzenia i rządzenia się własnym prawem wewnętrznym. Ustrojodawca litewski stanowi jednoznacznie, że „Kościoły i organizacje religijne bez przeszkód rządzą się swymi kanonami i statutami” (art. 43 zd. 4). Konstytucja Rumunii z 1991 r. stwierdza, iż „Wyznania religijne są wolne i organizują się zgodnie z ich statutami, na warunkach określonych ustawą" (art. 29 zd. 3) $)^{49}$.Zbliżoną treść zawiera art. 31 ust. 4 konstytucji Mołdawii. Wynika z tego, że autonomia związków wyznaniowych w państwie świeckim nie ma charakteru absolutnego, nie oznacza immunitetu prawnego związków wyznaniowych. Jej granicą jest ustawodawstwo (prawo) powszechnie obowiązujące.

Istnieje wreszcie nieliczna grupa konstytucji europejskich, która ogranicza się do zapewnienia związkom wyznaniowym niezależności lub autonomii w relacjach $\mathrm{z}$ państwem w sposób ogólny, wręcz ogólnikowy, tzn. bez precyzowania przedmiotu owej niezależności czy autonomii ${ }^{50}$. Specyficznie określono stosunki między państwem a Kościołem katolickim w konstytucji włoskiej (art. 7), stanowiąc: „Państwo i Kościół katolicki są, każde we własnym zakresie, niezależne i suwerenne" ${ }^{51}$. Należy odnotować, że postanowienie to nie przesądziło o świeckim charakterze Republiki Włoskiej. Do 1984 r. współobowiązywało bowiem z postanowieniem konkordatu laterańskiego z 1929 r. stanowiącym, że katolicyzm jest jedyną religią państwa włoskiego.

\section{Zasada równości związków wyznaniowych}

O wiele bardziej niż konstytucyjna formuła rozdziału państwa i związków urzeczywistnieniu koncepcji państwa świeckiego (laickiego) służy jurydyzacja w ustawie zasadniczej zasady równości związków wyznaniowych, równości wobec prawa tych podmiotów czy ich równouprawnienia. Przyjęcie tych norm wyklucza nadanie prawnie określonemu wyznaniu czy związkowi konfesyjnemu statusu państwowego lub dominującego. Powyższe zasady nieczęsto są konstytucjonalizowane w państwach europejskich mających charakter państw świeckich (laickich). Zasada równości wyznań wyprowadzana jest pośrednio z zasady równości obywateli wobec prawa czy zakazu dyskryminacji z powodów reli-

48 http://libr.sejm.gov.pl/tek01/txt/konst/litwa-a.html [dostęp: 15.12.2015].

49 http://libr.sejm.gov.pl/tek01/txt/konst/rumunia-2.html [dostęp: 15.12.2015].

50 Art. 25 ust. 3 Konstytucji RP z 1997 r., art. 10 ust. 4 konstytucji Albanii z 1998 r.

51 Konstytucja Republiki Wtoskiej, tłum. i wstęp. Z. Witkowski, Warszawa 2004, s. 58. 
gijnych. Różnie jest artykułowana przez ustrojodawcę. Konstytucja albańska z 1998 r. stwierdza bezpośrednio, że państwo uznaje równość wspólnot religijnych, konstytucje: Chorwacji z 1990 r., Macedonii z 1991 r., Rosji z 1993 r., Białorusi z 1994 r., Azerbejdżanu z 1995 r., Czarnogóry z 2007 r. mówią o równości wobec prawa. Ustrojodawcy słoweński w 1991 r. i polski w 1997 r. podkreślili, co zdecydowanie rzadsze, pozytywny aspekt omawianej zasady, deklarując równouprawnienie wspólnot wyznaniowych. Wyjątkowo mocno zasadę równości związków wyznaniowych podkreśla ustrojodawca serbski. W art. 44 konstytucji z 2006 r. dwukrotnie wyraża bezpośrednio zasadę równości Kościołów i wspólnot religijnych. Owa równość wiąże się zarazem z gwarancjami takiej samej wolności dla wymienionych podmiotów w dziedzinach: organizacji ich struktur wewnętrznych, w sprawach religijnych, w wykonywaniu obrzędów w miejscach publicznych, w tworzeniu i zarządzaniu szkołami religijnymi, instytucjami społecznymi i religijnymi.

Orzecznictwo konstytucyjne odrzuca $\mathrm{z}$ reguły bezwzględny egalitaryzm, pojmuje go w sposób relatywny. Niemiecki Związkowy Trybunał Konstytucyjny stwierdził, że „ustawa zasadnicza nie nakazuje, aby państwo schematycznie jednakowo traktowało wszystkie wspólnoty religijne"52, zaś belgijska Rada Stanu w 1966 r. uznała, iż równouprawnienie wyznań nie oznacza, że ten sam status ma być stosowany do wszystkich wy$z n a n^{53}$. Nawet we francuskim systemie relacji państwo - związki wyznaniowe, który jest systemem ścisłego równouprawnienia wyznań, stwierdza się, że to równouprawnienie nie jest de facto ścisłą równością ${ }^{54}$. Niekiedy konstytucja dopuszcza różnicowanie statusu związków wyznaniowych. Niemiecka ustawa zasadnicza wyróżnia związki wyznaniowe mające osobowość prawa publicznego, co oznacza posiadanie prawa do tzw. podatku kościelnego, oraz konfesje niemające tej cechy. Konstytucji litewskiej odnajdujemy bardziej rozbudowaną gradację. Dzieli ona związki wyznaniowe na uznane i nieuznane oraz wyróżnia tzw. tradycyjne Kościoły i organizacje religijne Litwy. Wyraźną aprecjację Kościoła katolickiego zakłada konstytucja włoska z 1947 r., przewidując relacje państwa z tym kościołem na zasadach swoistej równorzędności (art. 7), odmiennie niż stosunki

52 D. Hömig, W. Hassemer, Orzecznictwo sq̨ów konstytucyjnych w dziedzinie wolności wyznania. Krajowy raport Niemiec na XI Konferencje Europejskich Sądów Konstytucyjnych, 17-21 maja [1999 r.] w Warszawie [mps powiel.], ATK, s. 14, nlb.

53 E. Cerexhe, H. Boel, Orzecznictwo konstytucyjne w sprawach religijnych. Referat belgijski [mps powiel.], ATK, s. 28.

54 Orzecznictwo konstytucyjne w sprawach wolności religijnej..., op. cit., s. 44-45.

55 Szerzej: J. Kuznecoviene, Państwo i kościót na Litwie, [w:] Państwo i kościót w krajach Unii Europejskiej, red. G. Robbers, Wrocław 2007, s. 219-221. Podobnie w Austrii panuje zasada „równego (parytetowego) uznania”, w prawie państwowym nie ma zasady „absolutnie” równego traktowania towarzystw religijnych. Parytet w prawie materialnym dopuszcza zróżnicowanie pod warunkiem „merytorycznego uzasadnienia”, które może zwłaszcza wynikać z cech szczególnych danego związku wyznaniowego. Cf. G. Kucsko-Stadlmayer, Raport krajowy Austrii. Sytuacja prawna w kwestii wolności sumienia [mps powiel.], ATK. 
z pozostałymi związkami wyznaniowymi, dla których wyraźnie wskazano włoski porządek prawny jako granicę swobody działalności (art. 8). Najsłabszą forma aprecjacji jednego ze związków wyznaniowych jest wymienienie go z nazwy przez konstytucję, ale bez przyznawania mu szczególnych uprawnień materialnoprawnych. Ma to miejsce np. w konstytucji Hiszpanii z 1978 r. (art.16 ust. 3) oraz w konstytucji polskiej z 1997 r. (art. 25 ust. 4). Wydaje się, że - zgodnie ze standardami prawnomiędzynarodowymi - granicą dopuszczalnego zróżnicowania statusu prawnego związków wyznaniowych powinien być zakaz dyskryminacji ze względu na religię lub światopogląd. W państwie świeckim każdej grupie religijnej powinna być zapewniona możliwość prawnego istnienia.

\section{Neutralność światopoglądowa państwa}

Współcześnie za najistotniejszą cechę państwa laickiego (świeckiego) należy uznać jego neutralność światopoglądową. Neutralność, od łac. neutalis, semantycznie oznacza obojętność, bezstronność państwa, które powinno zachować „równą odległość” w stosunku do wszystkich występujących w społeczeństwie postaw światopoglądowych. Ugruntowanie analizowanej zasady ustrojowej w Europie to przede wszystkim rezultat orzecznictwa sądów konstytucyjnych oraz Europejskiego Trybunału Praw Człowieka. Zasada neutralności światopoglądowej państwa (władz publicznych) rzadko podlega bezpośredniej jurydyzacji w konstytucjach państw naszego kontynentu ${ }^{56}$. Konstytucja Albanii z 1998 r. w art. 10 ust. 2 stanowi, że państwo jest neutralne w sprawach wiary i sumienia oraz gwarantuje wolność ich ekspresji w życiu publicznym. Natomiast konstytucja Kosowa z 2008 r. wskazuje na bezpośredni związek świeckości państwa i jego neutralności światopoglądowej, stwierdza bowiem w art. 8: „Republika Kosowa jest państwem świeckim i neutralnym w sprawach wierzeń religijnych" ${ }^{57}$. Ustrojodawca polski głosi z kolei, że władze publiczne zachowują bezstronność $\mathrm{w}$ sprawach przekonań religijnych, światopoglądowych i filozoficznych gwarantując swobodę ich wyrażania w życiu publicznym (art. 25 ust. 2). Wykładnia językowa, a przede wszystkim historyczna terminu „bezstronność” nakazuje traktować go jako synonim terminu „neutralność” ${ }^{8}$.

56 Zasada neutralności państwa wobec religii została pierwszy raz bezpośrednio wyrażona w konstytucji Republiki Malgaskiej z 1960 r. W art. 2 czytamy m.in. „Stwierdza ona [Republika Malgaska - P.B.] swoją neutralność wobec różnych religii. Państwo i Kościoły korzystają z autonomii odpowiednich dziedzinach. Zakazane jest wszelkie ingerowanie w dziedzinę, która do nich nie należy”. Ustrojodawca malgaski nie zachował się przy tym konsekwentnie, ponieważ przewidział zarazem obligatoryjną przysięgę prezydenta państwa z elementami religijnymi (art. 9). Cf. Konstytucje państw afrykańskich, oprac. i wstęp L. Gelberg, t. II, Warszawa 1965, s. 118-121.

57 http://www.assembly-kosova.org/common/docs/Constitution1\%20of\%20the\%20Republic\% 20of\%20Kosovo.pdf [dostęp: 17.12.2015].

58 Wyczerpującą analizę konstytucyjnej zasady bezstronności światopoglądowej władz publicznych w prawie polskim przeprowadził W. Brzozowski w monografii pt. Bezstronność śrwiatopogladowa wtadz publicznych, Warszawa 2011. 
Z neutralnością światopoglądową państwa wiąże się neutralność szkolnictwa publicznego i odrzucenie w warunkach pluralizmu oświatowego modelu publicznej szkoły wyznaniowej. Państwo nie może, jak stwierdził w 1976 r. ustrojodawca portugalski, opracowywać programów edukacyjnych i kulturalnych, kierując się jakimikolwiek dyrektywami filozoficznymi, estetycznymi, politycznymi, ideologicznymi bądź religijnymi. Natomiast według konstytucji belgijskiej neutralność zakłada respektowanie koncepcji filozoficznych, ideologicznych lub religijnych rodziców i uczniów. Jednakże w opinii z 1989 r. włoskiego Sądu Konstytucyjnego, zbieżnej z przytoczonym wyżej stanowiskiem polskiego Trybunału Konstytucyjnego z 1991 r., zasada laickości państwa „nie zakłada obojętności państwa wobec religii, ale nakazuje państwu stworzenie gwarancji wolności religijnej w systemie pluralizmu wyznaniowego i kulturalnego" 59 . W obliczu przemian ustrojowych w Europie Środkowej i Wschodniej widoczne jest zwłaszcza zjawisko odchodzenia od czysto laickiego charakteru szkoły państwowej, charakterystycznego głównie dla ustrojodawstwa wprowadzającego system rozdziału w pierwszej połowie minionego wieku ${ }^{60}$.

\section{Współdziałanie państwa i związków wyznaniowych}

Świeckość państwa nie wymaga, aby ignorowało ono związki wyznaniowe jako uczestników życia społecznego. Państwo laickie może, a nawet powinno, podejmować wspóldziałanie czy wręcz współpracę w sprawach o charakterze ogólnospołecznym, takich jak pomoc społeczna, ochrona zabytków. Współdziałanie czy współpracę państwa i związków wyznaniowych przewidują ustrojodawcy: polski (art. 25 ust. 3), albański (art. 10 ust. 4) i hiszpański (art. 16 ust. 3). Pomoc państwa dla związków wyznaniowych w niektórych aspektach ich działalności przewidują konstytucje: Chorwacji (art. 41), Rumunii (art. 29 ust. 5) oraz Mołdowy (art. 31 ust. 5).

Z zasadą świeckości państwa nie koliduje zapewnienie przezeń opieki duszpasterskiej w państwowych instytucjach o charakterze zamkniętym, takich jak siły zbrojne, zakłady karne, skoszarowane jednostki policji, szpitale czy domy opieki. Wydaje się natomiast, że duchowni pełniący posługę w powyższych instytucjach, z uwagi na konieczność utrzymania rozdziału instytucjonalnego państwa i związków wyznaniowych, nie powinni posiadać statusu funkcjonariuszy państwowych, co najwyżej być zatrudnieni na podstawie takiego samego stosunku pracy jak pracownicy cywilni. Ustrojodawca niemiecki przewiduje dopuszczenie związków wyznaniowych do odprawiania czynności religijnych w wojsku, szpitalach, więzieniach i innych zakładach publicznych stosownie do odpowiednich potrzeb ludności, w wyłączeniem jednak wszelkiego przymusu ${ }^{61}$. Po-

59 L. Garlicki, op. cit., s. 44.

60 Cf. np. art. 3 ust. IV konstytucji Meksyku z 1917 r., art. 124 konstytucji ZSRR z 1936 r., art. 55 konstytucji Kuby z 1940 r., art. 201 konstytucji Salwadoru z 1950 r.

61 Cf. utrzymany w mocy art. 141 konstytucji weimarskiej z 11 sierpnia 1919 r. 
dobnie konstytucje Rumunii z 1991 r. i Mołdowy z 1994 r. gwarantują wyznaniom religijnym ułatwienie wsparcia religijnego w wojsku, w szpitalach, zakładach karnych, domach starców czy sierocińcach. Ich zniesienie sygnalizowałoby przyjęcie przez państwo nie polityki neutralności, lecz wrogości wobec religiii ${ }^{62}$.

System rozdziału nie wyklucza pewnej interferencji funkcjonalnej państwa i związków konfesyjnych. Kontynuując tradycje historyczne oraz uznając rolę społeczną dwóch wielkich Kościołów: katolickiego i ewangelickiego ${ }^{63}$ niemiecka ustawa zasadnicza przyznała związkom wyznaniowym o charakterze publicznoprawnym prawo pobierania podatków na podstawie cywilnych list podatkowych. Tzw. podatek kościelny (Kirchensteuer) jako „podatek członkowski” jest zatem egzekwowany przez państwowe organy finansowe ${ }^{64}$. Współcześnie odstępstwa od zasady separacji funkcjonalnej uzasadniane są dążeniem do zapewnienia pełnej realizacji wolności sumienia i wyznania ${ }^{65}$. Konstytucja litewska uznaje w związku z tym kościelną rejestrację małżeństw, przyznając duchownym de facto funkcję urzędników stanu cywilnego. Państwo podejmuje się także zapewnienia zainteresowanym nauki religii, co wyraźnie dopuszczają ustawy zasadnicze m.in. Rumunii, Czech, Niemiec, Belgii, Litwy, Polski czy Turcji. Symptomatyczne wydaje się w związku z tym stanowisko polskiego Trybunału Konstytucyjnego, który uznając konstytucyjność wprowadzenia nauki religii w szkołach publicznych, stwierdzit, że świeckość i neutralność państwa nie tylko nie może być podstawą wprowadzenia obowiązku nauczania religii w szkołach państwowych, ale nie może też oznaczać zakazu takiego nauczania, jeśli tego sobie życzą zainteresowani obywatele. Na tym właśnie polega, zdaniem Trybunału, świeckość i neutralność państwa. Inne rozumienie tych pojęć oznaczałoby nie neutralność, a ingerencję państwa w wolność sumienia i wyznania obywateli ${ }^{66}$.

Obecność pierwiastka religijnego w szkolnictwie państwowym (publicznym) to kwestia wciąż wywołująca dyskusje w wielu państwach europejskich. W europejskich państwach świeckich przeważa model fakultatywnej edukacji religijnej w szkołach podstawowych i ponadpodstawowych. Jest to uzasadniane przede wszystkim koniecznością uwzględnienia w procesie edukacji szkolnej prawa rodziców do wychowania dzieci zgodnie $\mathrm{z}$ ich przekonaniami w sprawach religijnych ${ }^{67}$. Laicki model edukacji szkolnej

62 R. Gordis, Separation - Theory and Practice, [w:] Religion and the Public Order, red. D.A. Gianella, Chicago 1963, s. 332, 333, 335.

63 Cf. W. Pięciak, Kryzys wiary czy kryzys systemu?, Warszawa 1999, s. 39-50.

64 Wyjątek stanowi Bawaria, gdzie ściąganiem podatku zajmują się urzędy kościelne. Cf. P. Leszczyński, O stosunkach państwo - Kościoty w Niemczech, „Res Humana” 1997, nr 6, s. 11-12.

65 Cf. J. Krukowski, Konkordat polski. Znaczenie i realizacja, Lublin 1999, s. 193-194.

66 Orzeczenie z dnia 30 stycznia 1991 r. (K. 11/90).

67 Np. art. 53 ust. 3 i 4 Konstytucji RP z 1997 r. czy art. 40 konstytucji Litwy z 1992 r. 
realizowany jest tylko w kilku państwach analizowanej grupy. Są to: Francja (z wyjątkiem Alzacji i Lotaryngii), Holandia, Słowenia, Ukraina, Białoruś, Rosja i Azerbejdżan ${ }^{68}$.

\section{Zakończenie}

We współczesnej Europie przeważają państwa, które w świetle ich aktów ustrojodawczych można zaklasyfikować jako państwa świeckie (laickie) przynajmniej w podstawowym znaczeniu tego terminu, czyli jako państwa niewyznaniowe. Zasada świeckości państwa nie jest obecnie wykorzystywana w Europie do walki ze związkami wyznaniowymi czy religią w ogóle. Przeważają państwa świeckie w znaczeniu laickości pozytywnej, otwartej, akceptującej obecność pierwiastka religijnego w sferze publicznej. Przyczyną upowszechnienia tego rodzaju państwowości było stanowisko Soboru Watykańskiego II (lata 1962-1965) oraz papieży posoborowych, odrzucające model państwa katolickiego jako model optymalny dla Kościoła katolickiego ${ }^{69}$. Innym czynnikiem sprzyjającym popularyzacji idei państwa świeckiego (niekonfesyjnego) był zapewne rozwój doktryny wolności i praw człowieka. Wyrazem tego procesu jest zwłaszcza Konwencja o Ochronie Praw Człowieka i Podstawowych Wolności (EKPC) z 1950 r. oraz sformułowane na jej podstawie orzecznictwo w sprawach wyznaniowych organów Rady Europy,

68 Cf. Lekcje religii w szkotach publicznych wybranych państw europejskich, „Gość Niedzielny” 2006, nr 36, s. 27. W Rosji i na Białorusi od 2010 r. może być nauczany fakultatywnie przedmiot o charakterze niekonfesyjnym Podstawy kultury prawosławnej. Jest on prowadzony przez nauczycieli świeckich dla starszej młodzieży szkolnej.

69 W Konstytucji duszpasterskiej o Kościele w świecie współczesnym stwierdzono m.in.: „Wspólnota polityczna i Kościół są w swoich dziedzinach od siebie niezależne i autonomiczne. Obydwie jednak wspólnoty, choć z różnego tytułu, służą powołaniu jednostkowemu i społecznemu tych samych ludzi. Tym skuteczniej będą wykonywać tę służbę dla dobra wszystkich, im lepiej będą rozwijać między sobą zdrową współpracę uwzględniając także okoliczności miejsca i czasu. [...] Nie pokłada [Kościół - P.B.] jednak swoich nadziei w przywilejach ofiarowanych mu przez władzę państwową; co więcej, wyrzeknie się korzystania z pewnych praw legalnie nabytych, skoro się okaże, że korzystanie z nich podważa szczerość jego świadectwa albo że nowe warunki życia domagają się innego układu stosunków. Kościół winien mieć jednak zawsze i wszędzie prawdziwą swobodę w głoszeniu wiary, w uczeniu swojej nauki społecznej, w spełnianiu nieskrępowanie wśród ludzi swego zadania, a także w wydawaniu oceny moralnej nawet w kwestiach dotyczących spraw politycznych, kiedy domagają się tego podstawowe prawa osoby lub zbawienie dusz, stosując wszystkie i wyłącznie te środki, które zgodne są z Ewangelią i dobrem powszechnym według różnorodności czasu i warunków”. V. Sobór Watykański II. Konstytucje. Dekrety. Deklaracje, Poznań 1967, s. 604. Z kolei w dekrecie o działalności misyjnej Kościoła znalazła się o wiele bardziej jednoznaczna deklaracja, iż Kościół „w żadnym wypadku nie chce wtrącać się w rządy ziemskiego państwa. Nie żąda dla siebie żadnej prerogatywy oprócz tej, aby pomocą Bożą mógł służyć miłością i wiernym posługiwaniem" (Sobór Watykański II..., op. cit., 448). Państwo świeckie zaakceptował wprost papież Paweł VI, stwierdzając w 1968 r.: „Kościół dzisiejszy nie boi się uznać wartości świata świeckiego, [...] nie boi się potwierdzić tego, co już otwarcie przyznał - słusznej i zdrowej świeckości państwa za jedną z zasad doktryny katolickiej” (M. Pietrzak, Prawo wyznaniowe, Warszawa 2010, s. 110). 
przede wszystkim Europejskiego Trybunału Praw Człowieka w Strasburgu. Obowiązek zachowania neutralności przez władze publiczne w sprawach religijnych to jedna z zasadniczych i trwałych tez orzecznictwa strasburskiego w związku z art. 9 EKPC, gwarantującym wolność myśli, sumienia i wyznania ${ }^{70}$. Tendencja do odchodzenia od modelu państwa wyznaniowego widoczna jest zwłaszcza w państwach nordyckich.

Nie ma powszechnie przyjętej w praktyce politycznej i ustrojowej szczegółowej koncepcji państwa laickiego (świeckiego) ${ }^{71}$. W Europie od ponad stu lat podlega ewolucji warunkowanej zarówno przez czynniki partykularne, charakterystyczne dla poszczególnych krajów jak i przez czynniki uniwersalne - paneuropejskie. Wyzwaniem dla koncepcji państwa świeckiego (laickiego) staje się współcześnie fundamentalizm islamski i stanowiąca reakcję nań ksenofobia ujawniająca się w wielu społeczeństwach europejskich. Część klasy politycznej w państwach Starego Kontynentu na tego rodzaju postawach buduje poparcie społeczne dla siebie i swoich partii. Religia znów okazuje się narzędziem mobilizacji elektoratu i uzyskania wpływów politycznych. Zorientowany ksenofobicznie elektorat oczekuje nadania państwu znamion etnicznych (nacjonalistycznych) lub konfesyjnych. Zasada państwa świeckiego (laickiego) jawi się jako bariera dla opisanych wyżej dążeń. Sprzyja ona inkluzywnej wizji państwa oraz pluralistycznej koncepcji społeczeństwa. Reasumując, można stwierdzić, że utrzymanie ustrojów demokratycznych w Europie wiąże się z respektowaniem zasady świeckości państwa, której najważniejszą cechą powinna być jego neutralność światopoglądowa.

\section{Literatura}

Borecki P., Elementy konfesjonalizacji państwa we wspótczesnej Polsce, [w:] Państwo wyznaniowe. Doktryna, prawo i praktyka, red. J. Szymanek, Warszawa 2011.

Borecki P., Laickośćpaństwa w świetle dorobku powojennego konstytucjonalizmu, [w:] Cuius regio, eius religio? Publikacja po Zjeździe Historyków Państwa i Prawa, t. I, Lublin 2006, t. II, Lublin 2008.

Cerexhe E., Boel H., Orzecznictwo konstytucyjne w sprawach religijnych. Referat belgijski [mps powiel.], ATK.

70 Konwencja o Ochronie Praw Cztowieka i Podstawowych Wolności, t. I. Komentarz do artykutów 1-18, red. L. Garlicki, Warszawa 2010, s. 560.

71 G. Haarscher wyróżnił dwie odmiany laickości państwa: tzw. laickość twardą, charakteryzującą się przede wszystkim absolutyzacją rozdziału (separacją) państwa i Kościoła, oraz tzw. laickość otwartą (szeroką), której zasadniczą cechą miałaby być neutralność państwa w sprawach religijnych czy niedyskryminacja z powodów religijnych. Jako przykład realizacji pierwszej koncepcji laickości wskazana została Francja ( $\mathrm{z}$ wyjątkiem Alzacji i Lotaryngii), natomiast jako przykład tzw. laickości otwartej podaje się Stany Zjednoczone Ameryki. V. G. Haarscher, op. cit., s. 113-120. 
190 | Adam Mickiewicz University Law Review

Frankowski S., Goldman R., Łętowska E., Sąd Najwyższy USA. Prawa i wolności obywatelskie, Warszawa 1996.

Garlicki L., Wolność sumienia i wyznania - status wspólnot religijnych, „Biuletyn Trybunału Konstytucyjnego" 1999.

Gordis R., Separation - Theory and Practice, „Religion and the Public Order” 1963.

Górowska B., Stosunki państwo - Kościót w konstytucjach państw postkomunistycznych, „Więż"1993, nr 6.

Haarscher G., Laickośc, Warszawa 2004.

Hömig D., Hassemer W., Orzecznictwo sqqdów konstytucyjnych w dziedzinie wolności wyznania. Krajowy raport Niemiec na XI Konferencje Europejskich Sq̨ów Konstytucyjnych, 17-21 maja [1999 r.] w Warszawie [mps powiel.], ATK.

Kuznecoviene J., Państwo i kościót na Litwie, [w:] Państwo i kościót w krajach Unii Europejskiej, red. G. Robbers, Wrocław 2007.

Konstytucje państw Unii Europejskiej, red. W. Staśkiewicz, Warszawa 2011.

Konstytucja Republiki Chorwacji, tłum. T.M. Wójcik, wstęp A. i L. Garliccy, Warszawa 1995.

Konstytucja Republiki Wtoskiej, tłum. i wstęp. Z. Witkowski, Warszawa 2004.

Konstytucje państw afrykańskich, t. II, oprac. i wstęp L. Gelberg, Warszawa 1965.

Krukowski J., Konkordat polski. Znaczenie i realizacja, Lublin 1999.

Leszczyński P., O stosunkach państwo - Kościoty w Niemczech, „Res Humana” 1997, nr 6.

Łakomy H., Państwo a Kościót we Francji. Historia i wspótczesność, Kraków 1999.

Pietrzak M., Demokratyczne, świeckie państwo prawne, Warszawa 1999.

Pietrzak M., Prawo wyznaniowe, Warszawa 2010.

Małajny R.M., Państwo świeckie (rozdziat kościota od państwa), [w:] Leksykon prawa wyznaniowego. 100 podstawowych pojęć, red. A. Mazglewski, Warszawa 2014.

Pięciak W., Kryzys wiary czy kryzys systemu?, Warszawa 1999.

\section{SUMMARY}

\section{The secular state in the context of the contemporary European constitutionalism}

In today's Europe the secular state dominates. Disseminating the principles of the secular state in Europe promotes the diversity of religious and philosophical populations. The principle of the secular state no longer serves to reduce the social significance of religion or religious organizations. A way of expressing the principle of secularism in constitutional acts is diverse - it is often necessary for complex analysis of the content of the constitution. The principle of the secular state is expressed in the constitutions of approximately $14 \%$ of European countries. State Secularism is often equated with the principle of separation of church and state. In Europe, however, there are examples 
of countries that are exceptions to this rule. In total, the formal separation of church and state is expressed in approximately $25 \%$ of the constitutions of European countries. Often the principle of this separation in the Basic Law is expressed in a veiled manner. The most important feature of a secular state is considered to be the modern principle of neutrality. However, it is rarely explicitly expressed in the Basic Law in Europe. Its spread was mostly driven by the constitutional court decisions and statements of the doctrine of the law.

Keywords: secularity, secular state, separation of church and state, neutral outlook of the state

Pawę Borecki, University of Warsaw, Faculty of Law and Administration, Institute of History of Law, Krakowskie Przedmieście 26/28, 00-927 Warszawa, Republic of Poland, e-mail: pawelborecki@op.pl. 